\title{
OS PRINCÍPIOS CONSTITUCIONAIS COMO GARANTIA DA POSSIBILIDADE JURÍDICA DE ADOÇÃO POR CASAIS HOMOAFETIVOS
}

\section{Sheila Maria Penno'}

Resumo: Trata o artigo da possibilidade jurídica de adoção por casais homoafetivos com fundamento nos princípios constitucionais da dignidade da pessoa humana, da igualdade, da ampla proteção à família e da proteção integral à criança e ao adolescente com vistas à defesa do melhor interesse e como garantia do reconhecimento de direitos. Conceitua família, reconhecendo àquela havida com fincas na afetividade, e, por meio de interpretação de princípios constitucionais, busca estabelecer garantias para o reconhecimento da possibilidade jurídica de adoção por casais de mesmo sexo. Logo, o mote do estudo revela-se diante da ausência de regulamentação legal e do evidente choque entre princípios, necessitando aferir o de maior grandeza, com vistas à garantia da efetivação da maior gama de direitos, mormente aos que se encontram à margem do ordenamento

1 Aluna da Escola Superior da Magistratura do Estado de Santa Catarina (ESMESC). Bacharel em Direito pela Universidade do Oeste de Santa Catarina UNOESC, Campus de Videira/SC (2002) e Pós-graduada em Direito Material e Processual Civil pelo Complexo de Ensino Superior de Santa Catarina - CESUSC (2010). E-mail: sheilapenno@hotmail.com 
jurídico, na proporção em que a mera ausência de expressão legal não pode mais ser admitida como impeditiva do reconhecimento de situações de fato que geram importantes consequências no campo jurídico.

Palavras-chave: Família. Princípios constitucionais. Condições da ação. Possibilidade jurídica do pedido.

\section{INTRODUÇÃO}

O tema tangencia a necessidade de efetuar precisa revisão nos valores pré-concebidos ao longo da história do direito de família e do direito civil, que obstam o reconhecimento das relações homoafetivas como entidades familiares, e, por consequência, impedem o reconhecimento de direitos e a aplicação de institutos, entre eles o da adoção.

A problemática é atual e urgente, na medida em que não se pode mais conceber a existência de relações, cujo cerne é o direito de família, à margem do ordenamento jurídico, principalmente quando a Constituição da República de 1988 veda discriminações de qualquer natureza.

Cediço que a união entre pessoas do mesmo sexo, atualmente, é uma realidade fática inegável. Em que pese as parcerias entre homossexuais remontarem os primórdios da história da Humanidade, cerrar os olhos para este fato significa corroborar a manutenção dessas relações à margem do ordenamento jurídico.

Por outro lado, incabível se admitir que crianças e adolescentes permaneçam abrigados e privados do convívio familiar, sob a justificativa de que o conceito de entidade familiar constitucionalmente aceito é o havido, tão-somente, entre um homem e uma mulher. Sugere-se, portanto, por meio de aplicação prática de princípios constitucionais ao direito de família a possibilidade jurídica de adoção por casais homoafetivos.

Para tanto, o desenvolvimento do trabalho utiliza método de abordagem dedutivo e métodos de procedimento histórico, comparativo. A técnica de pesquisa utilizada é a prescritiva, teórica em fontes primárias e secundárias. 
Inicialmente discorre-se sobre do instituto família, conceituando-a à luz do Direito Civil, na concepção clássica, assim como extensiva à união estável, com vistas àquela havida entre pessoas do mesmo sexo e o reconhecimento destas como grupo familiar, baseado na afetividade. Num segundo momento, debruça-se sobre princípios constitucionais que norteiam o direito de família e, por fim, abordam-se aspectos gerais sobre adoção, condições da ação, precisamente à possibilidade jurídica de adoção por casais homoafetivos.

A importância do tema repousa na inexistência de legislação específica sobre a qualificação jurídica e a possibilidade de reconhecimento das uniões homoafetivas como instituição familiar, assim como suas consequências fáticas no mundo jurídico.

\section{FAMÍLIA}

A compreensão e a extensão do conceito do termo família, inserido no contexto jurídico, dentre os institutos de direito comumente estudados, é o que sofreu maior influência das modificações impostas pelo decurso do tempo e pela evolução da própria sociedade, por isso mister a análise da evolução histórica do instituto.

\subsection{Evolução histórica}

Estabelecer uma noção ampla das modificações sofridas pelo instituto família pressupõe o estudo de concepções e do desenvolvimento histórico, considerando desde os primórdios das civilizações antigas ${ }^{2}$ até os dias atuais, na medida em que

2 "Reconstituindo retrospectivamente a história da família, Morgan chega, de acordo com a maioria de seus colegas, à conclusão de que existiu uma época primitiva em que imperava, no seio da tribo, o comércio sexual promíscuo, de modo que cada mulher pertencia igualmente a todos os homens e cada homem a todas as mulheres. No século passado, já se havia feito menção a esse estado primitivo, mas apenas de modo geral; Bachofen foi o primeiro - e este é um de seus maiores méritos - que o levou a sério e procurou seus vestígios nas tradições históricas e religiosas. (...) Aquele estado social primitivo, admitindo-se que tenha realmente existido, pertence a uma época tão remota que não podemos esperar encontrar provas diretas de sua existência, nem mesmo entre os fósseis sociais, nos selvagens mais atrasados (...)". (ENGELS, 1991, p. 31-32) 
as mudanças verificadas influem diretamente na formação e desenvolvimento de sua estrutura.

Verificando a importância dessas modificações, sustenta Peres (2006, p. 19) que "a família não é uma instituição estática e aistórica, por isso sofre influências diretas com as mudanças socioculturais e econômicas, que atingem sua estrutura e dinâmica”.

Por sua vez, Venosa (2008, p. 3) afirma que a própria sociedade com mentalidade urbanizada, embora não necessariamente urbana, cada vez mais exposta a fenômenos como a globalização, principalmente pelos meios de comunicação, pressupõe e define nova modalidade conceitual de família, consideravelmente distante das civilizações do passado.

Referido doutrinador expõe

No curso das primeiras civilizações de importância, tais como a assíria, egípcia, grega e romana, o conceito de família foi de entidade ampla e hierarquizada, retraindo-se hoje, fundamentalmente, para o âmbito quase exclusivo de pais e filhos menores, que vivem no mesmo lar.

Após, houve nova fase em que os primitivos buscavam manter relação com mulheres de outras tribos, referindo, historiadores, que esse fenômeno foi a primeira manifestação contra o incesto no meio social (exogamia ${ }^{3}$ ). (VENOSA, 2008, p. 3).

Engels (1991, p. 32) afirma que cada família primitiva teve de cindir-se com o passar das gerações, com a proibição das relações sexuais entre pais e filhos, irmãos e irmãs o grupo denominado família transforma-se numa gens, ou seja, num círculo fechado de parentes consanguíneos, que não podem casar uns com os outros.

Surge, portanto, imposição social crescente do ser humano buscar relações individuais, com características de exclusivi-

3 Exogamia (z) sf. Antrop. Costume social que prescreve entre indivíduos pertencentes a grupos ou subgrupos distintos. (FERREIRA, 2008) 
dade, atingindo-se a organização atualmente conhecida, cuja inspiração tem reflexos acentuados da monogamia ${ }^{4}$.

$\mathrm{Na}$ atualidade, percebe-se que a finalidade, composição e papel de pais e mães, modificou a instituição família, transformando sua estrutura, que deixou de ser uma unidade de produção na qual todos trabalham sob a autoridade de um chefe, para nova realidade na qual] o homem vai para a fábrica e a mulher lança-se para o mercado de trabalho. (VENOSA, 2008, p. 5).

Nesse contexto, Peres (2006, p. 19-20) constata profunda evolução do conceito de família, que engloba, além do modelo tradicional constituído pelo casamento, outras modalidades, como a união estável entre o homem e a mulher e a comunidade formada por qualquer dos pais e seus descendentes, as quais obtiveram o reconhecimento formal do Estado, sendo consideradas, cada qual, entidade familiar.

Arremata Venosa $(2008$, p. 6) que "em poucas décadas (...) os paradigmas do direito de família são diametralmente modificados". (...) $\mathrm{Na}$ ordem atual, portanto, os juristas começam a defrontar-se com um novel direito de família, que contém surpresas e desafios trazidos pela ciência.

As formas de constituição da família, instituição que dá sustento à sociedade, são detectadas, ao longo da história, com variações visíveis, na medida, por exemplo, dos valores morais ou religiosos de determinada época e da maior ou menor proteção jurídico-estatal. (SILVA JÚNIOR, 2007, p. 43).

Amarrado ao histórico acima exposto, no sistema jurídico brasileiro, no que se refere ao direito de família, a Constituição da República representou uma grande alavanca jurídica e sociológica. É nesse diploma que se encontram, expressamente, princípios acerca do respeito à dignidade da pessoa humana (art. $1^{\circ}$, III), entre outros que demonstram a efetiva intenção do legislador no que tange à proteção do instituto (VENOSA, 2008, p. 7).

4 Monogamia sf. Costume ou prática segundo a qual uma pessoa (homem ou muIher) não pode ter mais de um cônjuge. (FERREIRA, 2008) 
De modo semelhante, o Código Civil de 2002, em que pese não ter ousado abandonar arraigados princípios clássicos que norteiam a família patriarcal, compreendeu e incorporou os novos fenômenos da [família] contemporânea. (VENOSA, 2008, p. 7)

Monteiro (2004, p. 17) explica que o Código Civil de 2002, nas relações familiares, acentuou a necessidade de tutela dos direitos da personalidade, por meio da proteção à dignidade da pessoa humana, tendo em vista que a família deve ser havida como centro de preservação da pessoa, da essência do ser humano, antes mesmo de ser tida como célula básica da sociedade.

Atualmente, a sociedade contemporânea é chamada a enfrentar problemas da ordem da evolução do direito de família, discutindo-se nos tribunais o alcance dos direitos de pessoas do mesmo sexo que convivem, não havendo dúvidas das importantes modificações que serão objeto de discussão jurídica que cada vez ganha mais importância (...)”.

\subsection{Conceito e natureza jurídica}

Conceituar família ${ }^{5}$ implica destacar a diversificação do termo, que engloba tanto sentido genérico como biológico, considerando-se o conjunto de pessoas que descendem de um mesmo tronco ancestral, somando-se os filhos do cônjuge, os cônjuges dos filhos, os cônjuges dos irmãos e os irmãos do cônjuge (...). (PEREIRA, 2004, p. 19)

A mutação do termo família, antes entendida como aquela prevista pela Constituição de 1934, chamada de família legítima, ganhou novos contornos com a Constituição de 1988, que "deu maior amplitude ao conceito (...) abrangendo a família havida fora do casamento, com origem na união estável entre o homem e a mulher, bem como aquela composta por um dos progenitores e sua descendência (...)" (RODRIGUES, 2004, p. 4).

5 Família sf. 1. Pessoas aparentadas que vivem, ger., na mesma casa, particularmente o pai, a mãe e os filhos. 2. Pessoas do mesmo sangue. 3. Origem, ascendência. 4. Art. Gráf. O conjunto dos caracteres ou dos tipos com o mesmo desenho básico. 5. Biol. Reunião de gêneros [v. gênero (5)]. Antrop. A que é constituída pelo casal e seus filhos. (FERREIRA, 2008) 
Para Rodrigues (2004, p. 4) o vocábulo família é usado em vários sentidos, de acordo com o que se busca analisar dentro de determinado campo jurídico, podendo ser definida como formada por todas aquelas pessoas ligadas por vínculo de sangue, ou numa acepção um pouco mais limitada, poder-se-ia compreender a família como abrangendo os consanguíneos em linha reta e os colaterais sucessíveis (...).

Diniz (2009, p. 9) esclarece que "inúmeros são os sentidos do termo família, pois a plurivalência semântica é fenômeno normal no vocabulário jurídico". Com fundamento nessa premissa, referida autora delimita o sentido da palavra, prescrevendo que o termo, enquanto inserido na seara jurídica, possui três acepções clássicas, diferentes e igualmente fundamentais à compreensão do vocábulo:

(...) no sentido amplíssimo o termo abrange todos os indivíduos que estiverem ligados pelo vínculo da consanguinidade ou da afinidade, chegando a incluir estranhos, como no caso do art. 1.412, § $2^{\circ}$, do Código $\mathrm{Civil}^{6}$, em que as necessidades da família do usuário compreendem também as das pessoas de seu serviço doméstico. (...) $\mathrm{Na}$ acepção "lata", além dos cônjuges ou companheiros, e de seus filhos, abrange os parentes da linha reta ou colateral, bem como os afins (os parentes do outro cônjuge ou companheiro), como a concebem os arts. 1.591 e s. do Código Civil (...) Na significação restrita é a família (CF, art. 226, §§ $1^{\circ}$ e $2^{\circ}$ ) o conjunto de pessoas unidas pelos laços do matrimônio e da filiação, ou seja, unicamente os cônjuges e a prole (CC, arts. 1.567 e 1.716), e entidade familiar a comunidade formada pelos pais, que vivem em união estável, ou por qualquer dos pais e descendentes, como prescreve o art. 226, §§

6 Código Civil, art. 1.412. O usuário usará da coisa e perceberá os seus frutos, quanto o exigirem as necessidades suas e de sua família. $\S 1^{\circ}$ Avaliar-se-ão as necessidades pessoais do usuário conforme a sua condição social e o lugar onde viver. $\S 2^{\circ}$ As necessidades da família do usuário compreendem as de seu cônjuge, dos filhos solteiros e das pessoas de seu serviço doméstico. (BRASIL, 2009) - grifo nosso 
$3^{\circ}$ e $4^{\circ}$, da Constituição Federal, independentemente de existir o vínculo conjugal, que a originou (...). (DINIZ, 2009, p. 9-11)

Anote-se que a Constituição da República/1988 inovou ao afastar da conceituação constitucional a família compreendida, tão-somente, como aquela constituída por meio do casamento. (DINIZ, 2009, p. 11)

A partir do texto constitucional de 1988, inúmeros doutrinadores invocam classificação quanto às famílias, inicialmente, em duas grandes categorias, as constitucionais e as não-constitucionais. Coelho (2006, p. 15) explica que o conceito de família constitucional tem expressa previsão no art. 226 da Carta Magna, admitindo-a quando "instituída pelo casamento, pela união estável do homem e da mulher, assim como a família monoparental, ou seja, aquela formada por qualquer dos pais e seus descendes”.

Atualmente reconhece-se como família, dentro de uma concepção constitucional, tanto aquela decorrente do matrimônio, em paridade absoluta de condições, quanto aquela originada de união estável, a comunidade monoparental formada por qualquer dos pais e seus descendentes independentemente da existência de vínculo conjugal que a tenha originado, a formada por avós e netos, entre outras. (DINIZ, 2009, p. 11).

Percebe-se, efetivamente, que por tudo aquilo que representa, a família é compreendida universalmente como "célula social por excelência”, conceito que, como afirma Pereira (2004, p. 20) "de tanto se repetir, não se lhe aponta mais a autoria".

Como se vê, atualmente, o direito não engloba unicamente a família matrimonial em seu conceito, uma vez que protege também as uniões constituídas fora do casamento, bem como os vínculos de filiação formados por meio da adoção. "Deve-se, portanto, vislumbrar na conceituação de família uma possibilidade de convivência, marcada pelo afeto e pelo amor, fundada não apenas no casamento, mas também no companheirismo, a adoção e na monoparentalidade (...)” (DINIZ, 2009 p. 13). 
Nesse contexto, urge abarcar no conceito de família contemporânea a união homoafetiva, na proporção em que também é formada a partir do vínculo da afetividade, impondose o seu reconhecimento jurídico.

Em relação à natureza jurídica da família, é farto o entendimento e notória a concepção de que a família é reconhecidamente compreendida como uma instituição.

Extrai-se da doutrina majoritária, longe de ser homogênea, que o conceito de família deve ser interpretado como instituição. Nesse sentido, a família é considerada uma coletividade humana subordinada à autoridade e às condutas sociais. (VENOSA, 2008, p. 8)

Segundo referido autor, sob uma perspectiva sociológica, a família é

(...) uma instituição permanente integrada por pessoas cujos vínculos derivam da união de pessoas de sexo diversos. Desse modo, como sociologicamente a família é sem dúvida uma instituição, o Direito, como ciência social, assim a reconhece e a regulamenta. Recordemos que as instituições jurídicas são um universo de normas de direito organizadas sistematicamente para regular direitos e deveres de determinado fenômeno ou esfera social.

Assim, a família deve ser considerada o cerne de equilíbrio da sociedade em que o indivíduo está inserido, cabendo sedimentar os primeiros elementos necessários para o desenvolvimento e formação da personalidade dos seus membros, por meio da educação, transmitindo a cultura da sua sociedade. (CAVALCANTI, 2004, p. 20)

\subsection{União estável e união homoafetiva}

Conforme afirmado, com o advento da Constituição de 1988, a família brasileira ganhou novos contornos e foi submetida a importantes inovações, sendo um dos marcos principais 
o reconhecimento da união estável como família legítima. (SANTOS, 2005, p. 11)

O conceito tradicional de união estável pressupõe a existência de certos aspectos tidos como de relevante importância para sua configuração, considerando-se, em síntese, o relacionamento havido entre um homem e uma mulher que pretendem formar uma entidade familiar sem as formalidades atribuídas ao casamento. Nesse contexto, é considerada união estável aquela havida sem os formalismo do casamento entre um homem e uma mulher, com interesse de constituir família. (CAVALCANTI, 2004, p. 67-69)

O Código Civil de 2002, posterior, portanto, às leis n. 8.971/94 e n. 9.278/96 - que disciplinaram o direito dos companheiros a alimentos e à sucessão e definiu a moldura jurídica da união estável -, foi o diploma legal que trouxe substancial avanço no direito de família, inclusive tratando do tema em capítulo próprio.

Notadamente, o art. 1.723 do Código Civil reconhece a união estável como entidade familiar e disciplina os pressupostos para configurá-la, ficando caracterizada quando se verificar convivência pública, contínua, duradoura, com o objetivo de constituir família e entre homem e mulher. (SANTOS, 2005, p. 20)

Assim, infere-se que a própria lei expressamente qualifica a modalidade de convivência que autoriza o reconhecimento da existência de casamento de fato, tendo como requisitos a publicidade da convivência que se destine à finalidade de constituir família, a continuidade verificada pela ausência de interrupção e a durabilidade, compreendida como a relação não efêmera, ocasional ou transitória. (NERY JUNIOR; NERY, 2008, p. 1117).

De acordo com a legislação, a união estável, tradicionalmente, é compreendida como a convivência que se destina à formar um lar no qual se desfrute agradáveis momentos, bem como para repartição das dificuldades.

Por outro lado e não de somenos importância, cumpre mencionar que, consoante ensina Santos $(2005$, p. 2) a união 
estável não poderá ser reconhecida quando se verificar qualquer dos impedimentos matrimoniais, dentre aqueles previstos no art. 1.521, do Código Civil.

Cavalcanti (2004, p. 116) afirma que "a união estável só poderá ser caracterizada quando houver a vontade, o animus de constituir família. O que é realmente protegido pelo direito é a criação de um núcleo familiar”.

Neste contexto, é correto afirmar que a Constituição da República, quando atribuiu à união estável o status de entidade familiar, afastou desta estrutura os relacionamentos amorosos esporádicos, que não se pautam pela continuidade e durabilidade, bem como os que não possuem caracterizado de modo latente a intenção de formar família.

Amparando-se nos fundamentos que dão base à união estável e adentrando na temática convivência entre pessoas do mesmo sexo, vislumbra-se que tanto a doutrina, quanto a jurisprudência estão atentas às mudanças de paradigmas que alcançam a união homossexual, calcada na afetividade?. (MATOS, 2004, p. 7).

Welter (2007, p. 69) expõe que não obstante a família convivencial, na forma prevista pelo art. 226, $\S 3^{\circ}$, da CRFB, decorrer da formalizada entre o homem e a mulher, tem-se, atualmente, acolhido a união homoafetiva entre dois homens ou duas mulheres, cujo fundamento repousa no jeito de "ser família".

7 SOCIEDADE DE FATO. HOMOSSEXUAIS. PARTILHA DO BEM COMUM. O PARCEIRO TEM O DIREITO DE RECEBER A METADE DO PATRIMONIO ADQUIRIDO PELO ESFORÇO COMUM, RECONHECIDAA EXISTENCIA DE SOCIEDADE DE FATO COM OS REQUISITOS NO ART. 1363 DO C. CIVIL. RESPONSABILIDADE CIVIL. DANO MORAL. ASSISTENCIA AO DOENTE COM AIDS. IMPROCEDENCIA DA PRETENSÃO DE RECEBER DO PAI DO PARCEIRO QUE MORREU COM AIDS A INDENIZAÇÃO PELO DANO MORAL DE TER SUPORTADO SOZINHO OS ENCARGOS QUE RESULTARAM DA DOENÇA. DANO QUE RESULTOU DA OPÇÃO DE VIDA ASSUMIDA PELO AUTOR E NÃO DA OMISSÃO DO PARENTE, FALTANDO O NEXO DE CAUSALIDADE. ART. 159 DO C. CIVIL. AÇÃO POSSESSORIA JULGADA IMPROCEDENTE. DEMAIS QUESTÕES PREJUDICADAS. RECURSO CONHECIDO EM PARTE E PROVIDO. (...) É de se observar que nesse relacionamento não se há de ter preconceito quanto às preferências afetivas, sobretudo porque não se vê aí o exame de permissividade no meio social, mas, particularmente, a meu sentir, a busca da felicidade que tanto é procurada por todos nós e isso deve ser levado em consideração (...). (STJ, REsp 148897/MG, Rel. Min. Ruy Rosado de Aguiar, Quarta Turma, julgado em 10/02/1998, DJ 06/04/1998 p. 132) 
$\mathrm{O}$ autor menciona ainda que a jurisprudência tem afirmado que não é o fato de não existir lei que garanta proteção à união homoafetiva que faz desaparecer o fenômeno social, na medida em que está inserido na realidade da vida, no modo de "ser-no-mundo" dos homossexuais, pelo que a omissão do legislador não tem legitimidade de suprimir a homoafetividade. (WELTER, 2007, p. 71)

Para Fugie (2002, p. 135) não há obstáculos para que os efeitos da união estável sejam estendidos às relações homoafetivas, na medida em que a convivência diária, estável, sem impedimentos, livre, mediante comunhão de vida e de forma pública e notória na comunidade social é independente da orientação sexual de cada indivíduo.

Assim, enquanto o reconhecimento das uniões homoafetivas começa a ganhar espaço nos Tribunais do país, encontram na sociedade de fato a sua possibilidade de caracterização jurídica, gerando, por consequências, direitos para os parceiros, na medida da sua participação. (PEREIRA, 2004, p. 545)

Matos (2004, p. 15) enfoca que diante de inúmeras transformações percebe-se que o Direito Civil contemporâneo voltase constantemente para os valores essenciais da pessoa humana, sofrendo influência de um fenômeno chamado repersonalização ${ }^{8}$.

Nesse contexto, extraí-se que

o valor da dignidade da pessoa humana - consagrado no artigo $1^{\circ}$, inciso III da Constituição Federal de $1988^{9}$-, traduz essa noção para o ordenamento legislado. Os aspectos personalíssimos das pessoas devem ser o núcleo fundamental do

8 "A repersonalização das relações familiares significa uma preocupação com o desenvolvimento da personalidade das pessoas, sendo fundamental, nesse caminhar, o núcleo afetivo do agrupamento humano. Dessa maneira, as preocupações patrimoniais e as atenções à formalidade da constituição do vínculo que une as pessoas, como orientadoras das famílias, só encontram sentido ao atingirem o interesse precípuo do valor da dignidade. (MATOS, 2004, p. 16).

9 Art. $1^{\circ} \mathrm{A}$ República Federativa do Brasil, formada pela união indissolúvel dos Estados e Municípios e do Distrito Federal, constitui-se em Estado Democrático de Direito e tem como fundamentos: I - a soberania; II - a cidadania; III - a dignidade da pessoa humana; IV - os valores sociais do trabalho e da livre iniciativa; V - o pluralismo político. (BRASIL, 2009). 
sistema jurídico e a principal finalidade da proteção estatal. Assim, todas as demais normas do ordenamento devem cumprir essas unidades primeiras, sendo a dignidade do ser humano o elemento de convergência do sistema. (Matos, 2004, p. 15)

Diante disso, tem-se como necessidade premente o reconhecimento jurídico da convivência homoafetiva como união estável, na medida em que não se pode mais conceber que situações de fato, cada dia mais constantes, e que geram efeitos jurídicos importantes, mantenham-se à margem do ordenamento jurídico.

\subsection{Família homoafetiva}

Para Coelho (2006, p. 141), considerando-se o direito brasileiro atual, não há nada mais "desrespeitoso ao princípio constitucional da dignidade da pessoa humana que a ausência de disciplina legal da família constituída pela união de pessoas do mesmo sexo". E isso se dá em face de que os homossexuais não tem reconhecidos seus direitos em relação aos seus parceiros no que se refere ao vínculo da conjugalidade, na forma como os heterossexuais os têm.

Perquirindo-se meios pelos quais seja possível o reconhecimento jurídico da união homoafetiva como família, num primeiro momento surge, ainda que de modo singelo, o atrelamento à sociedade de fato, não correspondendo propriamente a uma novidade, posto que quanto à união estável, também utilizou-se dessa fórmula no início das transformações. (MATOS, 2004, p. 71)

No entanto, tal concepção ainda impede que se analise a união entre pessoas do mesmo sexo [homoafetiva] à luz do Direito de Família, e, por conseguinte, obsta que se reconheçam tais convivências como entidades familiares, nos mesmos moldes utilizados para o reconhecimento da união estável. (MATOS, 2004, p. 72) 
Welter (2007, p. 81) entende que "as circunstâncias de "serno-mundo afetivo" merecem pronta proteção estatal, visto que a hermenêutica filosófica tem como principal objetivo a procura da trajetória da vida, da realidade da história. (WELTER, 2007, p. 81)

Disso exsurge que, em que pese o reconhecimento das uniões homoafetivas como sociedades de fato representar solução para inúmeros dos problemas de ordem patrimonial, restringe-se ao campo do direito das obrigações, "desconsiderando-se a relação social existente como formadora de família", permanecendo no vácuo jurídico a necessária tutela da relação humana. (MATOS, 2004, p. 75)

Assim, acredita-se que a ausência previsão acerca da possibilidade jurídica de reconhecimento da convivência homoafetiva como entidade familiar fere os princípios da dignidade da pessoa humana e da igualdade, na medida em que não trata situações cujo cunho formador é idêntico - uniões fundamentadas na afetividade -, de modo equivalente.

Nesse sentido, considerando-se os inúmeros pontos em comum, Matos (2004, p. 84) menciona a existência de uma importante corrente doutrinária que defende posicionamento no sentido de que, enquanto não se tiver o reconhecimento expresso das relações homoafetivas, deve-se, analogamente, aplicar os textos legislativos relativos à união estável”.

Ao contrário de se buscar um tratamento que simplesmente transporte a união estável entre pessoas de mesmo sexo para o universo legislativo já amplamente difundido da união estável havida entre pessoas de sexo oposto, necessita-se, com vistas em um ordenamento constitucional interpretado de maneira sistemática, tutelar a parceria homoafetiva com fundamento nos princípios constitucionais. (MATOS, 2004, p. 86)

Por fim, afirma Matos (2004, p. 89) que tanto a união estável, quanto a união homoafetiva, tendo em foco serem efetivas uniões familiares não formalizadas, exigem análise e 
estudo com embasamento na sensibilidade para as especificidades de cada qual, perquirindo-se ampla tutela dos aspectos existenciais que lhes são peculiares, cujo fundamento está calcado nos princípios constitucionais da dignidade da pessoa humana, igualdade, e os decorrentes desses no que se refere à família.

\section{PRINCÍPIOS CONSTITUCIONAIS POSITIVOS}

Cediço que os princípios constitucionais positivos são caracterizados por princípios traduzidos em normas da Constituição ou que dela diretamente se inferem. (SILVA, 2008, p. 92)

Nahas (2008, p. 39) explica que a normatização constitucional distingue-se entre princípios e regras. Ao passo que existem, por conseguinte, inúmeros critérios, como o grau de abstração que é maior em relação aos princípios, o grau de determinabilidade no caso concreto, a necessidade de os princípios ter mediação aplicadora, enquanto que as regras aplicam-se diretamente, o caráter de fundamentalidade, na proporção em que os princípios são normas com papel fundamental.

Nesse contexto, afirma Canotilho (2003, p. 243-245) que os princípios constitucionais são basicamente de duas categorias: os princípios políticos-constitucionais e os princípios jurídicos-constitucionais.

Silva (2008, p. 93) elucida que os princípios políticos-constitucionais são aqueles decorrentes de decisões políticas fundamentais concretizadas em normas conformadoras do sistema constitucional positivo, e são normas-princípios ${ }^{10}$.

Por outro lado, os princípios jurídico-constitucionais são os informadores da ordem jurídica nacional, decorrem, portanto,

10 "Normas fundamentais que derivam logicamente (e em que, portanto, já se manifestam implicitamente) as normas particulares regulando imediatamente relações específicas da vida social. Manifestam-se como princípios constitucionais fundamentais conformadoras da Constituição, segundo Gomes Canotilho, ou, de outro quadrante, são decisões políticas fundamentais sobre a particular forma de existência política da nação, na concepção de Carl Schmitt. (SILVA, 2008, p. 93) 
de certas normas constitucionais e, não raramente, constituem desdobramentos ou princípios derivados dos princípios fundamentais $^{11}$. (SILVA, 2008, p. 93)

Cumpre, ainda, abordar o entrelaçamento entre princípios constitucionais e direitos fundamentais, conquanto, para Bonavides (2088, p. 256) princípios são as premissas de todo um sistema, enquanto os direitos fundamentais são o oxigênio das Constituições democráticas.

Interessam à temática em estudo os princípios da dignidade da pessoa humana, da igualdade e os relacionados à família - proteção da família e proteção à criança (adotando) -, compreendidos a partir da premissa "afetividade".

\subsection{Do princípio dignidade da pessoa humana}

Moraes (2003, p. 73) explica que a expansão da aplicação da proteção da pessoa humana, em constante substituição à tutela da liberdade individual "é o postulado a partir do qual se pode demonstrar toda a gama de transformações ocorridas no interior da ordem civil, a aplicação da lei pelos juízes e principalmente, na consciência moral da sociedade".

Nesse sentido, busca em Canotilho (2003, p. 225) definição primeira sobre tal princípio, pela qual afirma que "outra esfera constitutiva da República (...) é a dignidade da pessoa humana".

Disso decorre, inicialmente, que a República Federativa do Brasil, formada pela união indissolúvel dos Estados, Municípios e do Distrito Federal, é um Estado democrático de direito e tem como fundamentos a soberania, a cidadania, a dignidade

11 SILVA (2007, p. 93) exemplifica: “(...) o princípio da supremacia da constituição e o consequente princípio da constitucionalidade, o princípio da legalidade, o princípio da isonomia, o princípio da autonomia individual, decorrente da declaração dos direitos sociais, o da proteção da família, o ensino e da cultura, o da independência da magistratura, o da autonomia municipal, os da organização e representação partidária, e os chamados princípios-garantias (o do nullum crimen sine lege e da nulla poena sine lege, o do devido processo legal, o do juiz natural, o do contraditório entre outros, que figuram nos incs. XXXVIII a LX do art. $5^{\circ}(\ldots)$ 
da pessoa humana, os valores sociais do trabalho e da livre iniciativa e o pluralismo político ${ }^{12}$.

Assim, vê-se que muito mais do que um princípio a nortear a ordem constitucional e as relações havidas entre Estado e cidadãos e cidadãos entre si, a dignidade da pessoa humana é um dos fundamentos da República Federativa do Brasil.

Canotilho (2003, p. 225) ensina uma República fundamentada na dignidade da pessoa humana toma em consideração o princípio material subjacente à idéia de dignidade da pessoa humana. Trata-se de princípio que colhe a idéia prémoderna e moderna da dignitas-hominis, ou seja, "do indivíduo conformador de si próprio e da sua vida segundo o seu próprio projeto espiritual".

Para Moraes (2005, p. 16) a dignidade da pessoa humana concede unidade aos direitos e garantias fundamentais, sendo inerente à personalidade humana, afirmando

esse fundamento afasta a idéia de predomínio das concepções transpessoalistas de Estado e Nação, em detrimento da liberdade individual. A dignidade é um valor espiritual e moral inerente à pessoa, que se manifesta singularmente na autodeterminação consciente e responsável da própria vida e que traz consigo a pretensão ao respeito por parte das demais pessoas, constituindo-se um mínimo invulnerável que todo estatuto jurídico deve assegurar, de modo que, somente excepcionalmente, possam ser feitas limitações ao exercício dos direitos fundamentais, mas sempre sem menosprezar a necessária estima que merecem todas as pessoas enquanto seres humanos (...). (MORAES, 2005, p. 16)

Ao tema em foco, entretanto, importa como princípio informador das relações entre os indivíduos que compõe a

12 Art. $1^{\circ} \mathrm{A}$ República Federativa do Brasil, formada pela união indissolúvel dos Estados e Municípios e do Distrito Federal, constitui-se em Estado Democrático de Direito e tem como fundamentos: I - a soberania; II - a cidadania; III - a dignidade da pessoa humana; IV - os valores sociais do trabalho e da livre iniciativa; V - o pluralismo político. (BRASIL, 2009) 
sociedade, bem como no que diz respeito ao Estado, enquanto gestor da ordem jurídica.

Moraes (2003, p. 86) elucida que o fundamento jurídico do princípio da dignidade da pessoa humana manifesta-se, no princípio da igualdade, ou seja, no direito de não receber tratamento discriminatório, na garantia de ter direitos iguais assegurados a todos, consoante a mais pura aplicação do postulado "todos são iguais perante a lei".

O princípio da dignidade da pessoa humana, elucida Tavares (2006, p. 492), "encontra, assim como o direito à vida, alguns obstáculos no campo conceitual (...), dificuldades que são próprias dos princípios, normas que são extremamente abstratas e que permitem diversas considerações, definições e enfoques."

Silva (2008, p. 94) explica que a dignidade da pessoa humana, ao lado de outros como o da cidadania, do pluralismo, da soberania popular, da representação política e o princípio da participação popular direta (art. 1º, parágrafo único), é um princípio relativo ao regime político.

Assim, concordam os autores que o fato de a Constituição da República não inserir a dignidade da pessoa humana entre os direitos fundamentais do cidadão, expressos no extenso rol do art. 5, mas sim, considerá-la um dos fundamentos da República Federativa do Brasil, como prevê o inciso III do art. 1。, evidencia que o objetivo constitucional é demonstrar que a pessoa é o fundamento e fim da sociedade, tendo o Estado como maior finalidade a preservação da dignidade do homem.

Os autores convergem quanto ao fato que definir a dignidade da pessoa humana é tarefa árdua, considerando-se ser categoria jurídica principiológica, com natural característica de alto grau de abstração, permitindo contemplar a existência das mais variadas definições e conceituações. Todavia, inobstante a existência de discrepâncias, chegou-se a um conceito diante do qual se considera o homem como "ser em si mesmo" e não como "instrumento para um fim". 
Pode-se afirmar, portanto, que o homem, por ter dignidade, deve ser respeitado, estando acima de qualquer outra valoração.

Complementado, ainda, a dignidade da pessoa humana, enquanto princípio, tem dupla dimensão, negativa e positiva, ou seja, é a garantia negativa de que a pessoa não será alvo de ofensas ou humilhações, mas também agrega caráter positivo no sentido do pleno desenvolvimento da personalidade de cada indivíduo. (MORAES, 2005, p. 16)

Portanto, verifica-se que muito mais do que um princípio constitucional, a dignidade da pessoa humana tem características basilares e orientadoras de toda ordem jurídica brasileira. E, consubstanciado neste aspecto, "exprime a abertura da República à idéia de comunidade constitucional inclusiva pautada pelo multiculturalismo mundidencial, religioso ou filosófico". (CANOTILHO, 2003, p. 226)

A partir desta idéia de inclusão, constitucionalmente prevista e exigida tanto dos cidadãos, quanto do Estado, tem-se no princípio da dignidade da pessoa humana fundamento jurídico ao reconhecimento das uniões homoafetivas como instituições familiares, assim como da possibilidade jurídica de adoção por casais homoafetivos.

No que respeita à temática, portanto, vê-se que as constantes conquistas e as necessidades de afirmação de direitos têm sido objetivos de extrema importância para os homossexuais, na medida em que as reivindicações pelo reconhecimento legislativo e judicial de seus direitos ganha contorno nacional. (RIOS, 2007, p. 401)

Diante desse novo panorama jurídico nacional, donde a família pós-moderna se apresenta de forma plural, edificada sobre alicerces afetivos, como anteriormente abordado, e com amparo constitucional de inclusão, cujo princípio basilar é a dignidade da pessoa humana, infere-se que há espaço suficiente no ordenamento jurídico para se tutelar a adoção por homos- 
sexuais, quer seja o pedido realizado de modo conjunto entre os companheiros, quer seja realizado individualmente (PERES, 2006, p. 11-12)

\subsection{Do princípio da igualdade}

Apresenta-se como direito à igualdade dirigido a todos os cidadãos, ou como princípio inserido no sistema constitucional brasileiro, cuja finalidade é uniformizar o regime das liberdade individuais.

$\mathrm{O}$ art. 5, I, da CRFB/1988 expressamente prevê que "todos são iguais perante a lei, sem distinção de qualquer natureza, garantindo-se aos brasileiros e aos estrangeiros residentes no País a inviolabilidade do direito à vida, à liberdade, à igualdade, à segurança e à propriedade.

Com efeito, Canotilho (2003, p. 426) exterioriza que "um dos princípios estruturantes do regime geral dos direitos fundamentais é o princípio da igualdade. A igualdade é, desde logo, a igualdade formal ${ }^{13}$ ".

Para Silva (2008, p. 212) há os que sustentam que a desigualdade é característica intrínseca ao universo, não passando a igualdade de mero nome, sem qualquer significação no mundo real $^{14}$, assim como aqueles que defendem um igualitarismo absoluto entre as pessoas ${ }^{15}$.

Mencione-se, ainda, uma posição denominada realista, para o qual os homens são desiguais sob múltiplos aspectos, mas também compreende-os, de modo supremo, como seres iguais, uma vez que, em cada qual o "mesmo sistema de características inteligíveis proporciona, à realidade individual, aptidão para existir”. (Silva, 2008, p. 212).

13 Canotilho (2003, p. 4256) explica que se trata da igualdade jurídica, da igualdade liberal estritamente postulada pelo constitucionalismo liberal: os homens nascem e permanecem livres e iguais em direitos.

14 Teoria nominalista. Para seus adeptos os seres humanos, ao contrário do que expõe 0 art. $1^{\circ}$ da Declaração dos Direitos do Homem e do Cidadão de 1789, nascem e perduram desiguais. (SILVA, 2008)

15 Teoria idealista. Seus idealizadores afirmam haver uma igualdade natural ligada à hipótese do estado de natureza, em qu reinava a igualdade absoluta. (SILVA, 2008) 
No que respeita ao ordenamento constitucional em que está precipuamente inserido, Moraes (2005, p. 31) ensina que a Constituição da República consolidou o princípio da igualdade de direitos, ou seja, que "todos os cidadãos têm o direito de tratamento idêntico pela lei, em consonância com os critérios albergados pelo ordenamento jurídico".

Canotilho (2003, p. 426) discrimina como traços importantes do consagrado princípio, primordialmente, a igualdade na aplicação do direito afirmado que todos são iguais perante a lei. Num segundo momento, dispõe acerca da igualdade quanto à criação do direito, posto que a própria lei deve tratar por igual todos os cidadãos.

Assim, o que veda peremptoriamente a Constituição da República "são as diferenciações arbitrárias, as discriminações absurdas, pois, o tratamento desigual aos casos desiguais na medida em que se desigualam, é exigência tradicional do próprio conceito de Justiça”. (MORAES, 2005, p. 31)

Por conseguinte, num ou noutro sentido puramente conceitual, ou mesmo considerando a abrangência do conteúdo, essencialmente, não há como se afastar do reconhecimento da igualdade entre os homens.

Importa ao tema, com fins a adentrar no conteúdo do princípio da igualdade diretamente relacionado aos indivíduos enquanto inseridos na sociedade, que o art. 5 I, da CRFB assinala a igualdade entre homens e mulheres ${ }^{16}$.

Moraes (2005, p. 517) explica que

a correta interpretação desse dispositivo torna inaceitável a utilização do discrímen sexo, sempre que o mesmo seja eleito com o propósito de desnivelar materialmente o homem da mulher; aceitando-o, porém, quando a finalidade pretendida

16 "Art. $5^{\circ}$ Todos são iguais perante a lei, sem distinção de qualquer natureza, garantindo-se aos brasileiros e aos estrangeiros residentes no País a inviolabilidade do direito à vida, à liberdade, à igualdade, à segurança e à propriedade, nos termos seguintes: I - homens e mulheres são iguais em direitos e obrigações, nos termos desta Constituição; (...)". (BRASIL, 2009) 
for atenuar os desníveis. Consequentemente, além dos tratamentos diferenciados entre homens e mulheres previstos pela própria constituição (arts. $7^{\circ}$, XVIII e XIX ${ }^{17} ; 40, \S 1^{\circ}$ e $2^{\circ 18} ; 201$, § $7^{\circ 19}$ ), poderá a legislação infraconstitucional pretender atenuar os desníveis de tratamento em razão do sexo.

Tavares (2006, p. 517) expõe que o tema igualdade entre os sexos sempre diferencia-se cujo tratamento deve ser mais cuidadoso. O legislador constituinte, embora proíba a discriminação em função do sexo, não se absteve, entretanto, de lançar no próprio texto constitucional hipóteses de diferenciações entre homens e mulheres, de maneira bastante explícita, como se viu acima.

Por conseguinte, a respeito do princípio da igualdade aplicado às relações homoafetivas, Peres $(2006$, p. 111) afirma que a Constituição deu largo passo na superação do tratamento desigual fundado no sexo, ao equiparar os direitos e obrigações de homens e mulheres.

Santos (2008, p. 20) ilustra que já se tem bom exemplos de intervenção judicial no que tange à proteção jurídica alcançada

17 "Art. $7^{\circ}$ São direitos dos trabalhadores urbanos e rurais, além de outros que visem à melhoria de sua condição social: (...) XVIII - licença à gestante, sem prejuízo do emprego e do salário, com a duração de cento e vinte dias; (...) XIX - licençapaternidade, nos termos fixados em lei; (...)". (BRASIL 2009)

18 Art. 201. A previdência social será organizada sob a forma de regime geral, de caráter contributivo e de filiação obrigatória, observados critérios que preservem o equilíbrio financeiro e atuarial, e atenderá, nos termos da lei, a: (...)

$\S 7^{\circ}$ É assegurada aposentadoria no regime geral de previdência social, nos termos da lei, obedecidas as seguintes condições: (...). (BRASIL, 2009)

19 Art. 226. A família, base da sociedade, tem especial proteção do Estado. $\S 1^{\circ}-0$ casamento é civil e gratuita a celebração. $\S 2^{\circ}-\mathrm{O}$ casamento religioso tem efeito civil, nos termos da lei. $\S 3^{\circ}-$ Para efeito da proteção do Estado, é reconhecida a união estável entre o homem e a mulher como entidade familiar, devendo a lei facilitar sua conversão em casamento. $\S 4^{\circ}$ - Entende-se, também, como entidade familiar a comunidade formada por qualquer dos pais e seus descendentes. $\S 5^{\circ}$ - Os direitos e deveres referentes à sociedade conjugal são exercidos igualmente pelo homem e pela mulher. $\S 6^{\circ}-\mathrm{O}$ casamento civil pode ser dissolvido pelo divórcio, após prévia separação judicial por mais de um ano nos casos expressos em lei, ou comprovada separação de fato por mais de dois anos. $\S 7^{\circ}-$ Fundado nos princípios da dignidade da pessoa humana e da paternidade responsável, o planejamento familiar é livre decisão do casal, competindo ao Estado propiciar recursos educacionais e científicos para o exercício desse direito, vedada qualquer forma coercitiva por parte de instituições oficiais ou privadas. $\S 8^{\circ}-O$ Estado assegurará a assistência à família na pessoa de cada um dos que a integram, criando mecanismos para coibir a violência no âmbito de suas relações. (BRASIL, 2009) 
por casais homoafetivos. Nestes casos, "aplicando-se o princípio constitucional da igualdade, as decisões judiciais têm atribuído direitos aos companheiros homossexuais a despeito da inexistência de uma lei específica que tutela seus interesses".

Diante de tal posicionamento, exsurge que o princípio da igualdade deve ser considerado, também, fundamento para o reconhecimento de direitos havidos entre casais homoafetivos, transpondo-se, no mesmo sentido, como embasamento garantidor do reconhecimento da possibilidade jurídica de adoção.

\subsection{Do princípio da proteção à família}

A família, considerada base da sociedade, aufere proteção especial do Estado, estampada no próprio texto Constituição da República, conquanto se infere do art. 226 e seus parágrafos ${ }^{20}$.

Portanto, a família é vista como instituição afirmada como a base da sociedade e, por isso, tem especial proteção do Estado, que é exercida por meio de assistência a pessoa de cada um dos que a integram e da criação de mecanismos para coibir a violência no âmbito de suas relações, não sendo mais compreendida, tão-somente, como aquela formada pelo casamento. (SILVA, 2008, p. 850)

Não obstante, a atual discussão que norteia a constitucionalidade deste dispositivo, para Fugie (2002, p. 132) há necessidade de se valorar a homossexualidade porquanto encontra respaldo na categoria "liberdade de opção sexual", e é considerada, assim, direito de personalidade.

Nesse norte, extrai-se que a Constituição da República ao garantir ampla proteção à instituição família, compreende, tradicionalmente, em seu termo três espécies de entidades familiares, a saber, aquela constituída pelo casamento civil ou religioso com efeitos civis ${ }^{21}$, a constituída pela união estável entre o homem e a mulher, devendo a lei facilitar sua conversão e

$20 \mathrm{CF}$, art. $226, \S \S 1^{\circ}$ e $2^{\circ}$;

$21 \mathrm{CF}$, art. 226, § $3^{\circ}$; 
casamento $^{22}$ e, ainda, a comunidade formada por qualquer dos pais e seus descendentes ${ }^{23}$. (MORAES, 2005, p. 745)

Silva (2008, p. 850) afirma que além da entidade familiar advinda do casamento, deve ser também reconhecida como tal e protegida pelo Estado, a comunidade formada por qualquer dos pais e seus descendentes e também, a união estável entre homem e mulher, cumprindo a lei facilitar sua conversão em casamento. (SILVA, 2008, p. 850)

Assim, vislumbra-se que, partindo do conceito de entidade familiar, a Constituição estabeleceu inúmeras regras de regência das relações familiares, as quais estão explicitadas nos parágrafos que decorrem no art. 226, CRFB/1988 e que complementam seu conteúdo, cuja finalidade é primar por sua ampla proteção.

Dentre as citadas regras, ensina Moraes (2005, p. 745), que estreitamente relacionada com o princípio de igualdade, advém a determinação de que os direitos e deveres referentes à sociedade conjugal são exercidos igualmente por aqueles que a compõem.

Tal posicionamento é a consagração do princípio da igualdade. Afirma Silva (2008, p. 850) que os direitos e deveres advindos da sociedade conjugal devem ser exercidos igualmente por seus componentes, especificando assim, o direito à igualdade expressamente consignado no art. 5º I, da CRFB/1988.

Considerando ainda as regras acerca da proteção à família, Moraes (2005, p. 746) inclui a adoção mencionando que "será assistida pelo poder público, na forma da lei, que estabelecerá casos e condições de sua efetivação por parte de estrangeiros”.

No que respeita à filiação, enfatiza ainda referido doutrinador, que os filhos, havidos ou não da relação do casamento, ou por adoção, terão os mesmos direitos e qualificações, proi-

$22 \mathrm{CF}$, art. 226, $\S 4^{\circ}$.

23 Art. $5^{\circ}$ Todos são iguais perante a lei, sem distinção de qualquer natureza, garantindo-se aos brasileiros e aos estrangeiros residentes no País a inviolabilidade do direito à vida, à liberdade, à igualdade, à segurança e à propriedade, nos termos seguintes: (...) $\S 2^{\circ}-$ Os direitos e garantias expressos nesta Constituição não excluem outros decorrentes do regime e dos princípios por ela adotados, ou dos tratados internacionais em que a República Federativa do Brasil seja parte. 
bindo expressamente a CRFB/1988 quaisquer designações discriminatórias relativas à filiação. (MORAES, 2005, p. 746)

Logo, da análise esmiuçada do art. 226 e seus parágrafos (CRFB/1988), vê-se a preocupação do legislador constitucional quanto a proteção da família, posto que é a base formadora da sociedade.

Nesse contexto, considerando-se a necessidade de inclusão da união homoafetiva como entidade familiar, com fins de receber, igualmente, a ampla e necessária proteção estatal, tem-se nos princípios da dignidade da pessoa humana e da igualdade, forte embasamento jurídico garantidor de seu reconhecimento jurídico, bem como, por extensão, dos direitos, garantias e obrigações, advindas de tal reconhecimento jurídico.

\subsection{Do princípio do melhor interesse da criança}

O grande desafio que a presente abordagem impõe, na medida em que a aplicação dos princípios anteriormente estudados exige, tão-somente, interpretação extensiva às uniões homoafetivas, cuja obrigatoriedade de aplicação exsurge dos próprios princípios inseridos no texto da CRFB/1988 - dignidade da pessoa humana e igualdade -, diz respeito a estabelecer a base constitucional acerca do princípio do melhor interesse da criança.

Peres (2006, p. 126) enfatiza que o princípio do melhor interesse da criança "vigora em nosso sistema jurídico por força do art. $5^{\circ}$, § 2० da Constituição da República e da Convenção Internacional dos Direitos da Criança, ratificada pelo Brasil através do Decreto n. 99.710/90", sendo, portanto, norma cogente, de obrigatória observação.

Este princípio, entrelaçado aos demais, dá respaldo jurídico a possibilidade jurídica de adoção por casais homoafetivos, porquanto traz entranhado em sua definição o sustentáculo do interesse de agir. 
Nesse contexto, a família, por ser instituição que recebe ampla proteção estatal, não tem somente direitos, mas tem, também, o dever, aliada à sociedade e ao Estado, de assegurar, com absoluta prioridade, os direitos fundamentais da criança e do adolescente, enumerados no art. $227^{24}$, da Constituição da República Federativa do Brasil. (SILVA, 2008, p. 851)

Estes direitos estão descritos no texto da Carta Magna, e dizem respeito ao direito à vida, à saúde, à alimentação, à educação, ao lazer, à profissionalização, à cultura, à dignidade, ao respeito, à liberdade e à convivência familiar e comunitária, além de colocá-los a salvo de toda forma de negligência, discriminação, exploração, violência, crueldade e opressão. (BRASIL, 2009)

Ao Estado, portanto, cumpre sua obrigação constitucional de promover programas de assistência integral à saúde da criança e do adolescente, admitida a participação de entidades não governamentais e obedecendo determinados preceitos.

Para Silva (2008, p. 851) o reconhecimento constitucional da igualdade de direitos e qualificações aos filhos, havidos ou não da relação de casamento, ou por adoção, proibidas quaisquer discriminações a ela relativas, é norma de fundamental importância.

$\mathrm{O}$ autor relembra que

ficam banidas da legislação civil expressões como filhos legítimos, filhos naturais, filhos adulterinos, filhos incestuosos. Por outro lado, expressamente é admitida a adoção de crianças brasileiras por estrangeiros, desde que seja assistida pelo Poder Judiciário, na forma da lei e nos casos e condições por esta estabelecidos (art. 227, § 5025). (SILVA, 2008, p. 851)

24 Art. 227. É dever da família, da sociedade e do Estado assegurar à criança e ao adolescente, com absoluta prioridade, o direito à vida, à saúde, à alimentação, à educação, ao lazer, à profissionalização, à cultura, à dignidade, ao respeito, à liberdade e à convivência familiar e comunitária, além de colocá-los a salvo de toda forma de negligência, discriminação, exploração, violência, crueldade e opressão.

25 Art. 227. (...) $\S 5^{\circ}$ - A adoção será assistida pelo Poder Público, na forma da lei, que estabelecerá casos e condições de sua efetivação por parte de estrangeiros. (BRASIL, 2009) 
Nesse ínterim, começa a ganhar espaço a discussão respeito de que as "crianças e os adolescentes são sujeitos de direitos, titulares de direitos fundamentais, reconhecidos pelo sistema jurídico pátrio e pela Doutrina da Proteção Integral”. (PERES, 2006, p. 127)

Dessa orientação, vê-se que os direitos expressos na CRFB/1988 têm por objetivo garantir especial proteção, salvaguardando os interesses das crianças e dos adolescentes, inclusive por meio da adoção, mormente considerando-se que a Constituição da República expressamente privilegia o vínculo familiar (art. 227), assim como o faz o Estatuto da Criança e do Adolescente (Lei n. 8.069/90), embora enfatizando os laços biológicos, não afasta a possibilidade jurídica de a criança ou o adolescente ser criado e educado por família substituta. (PERES, 2006, p. 130)

Considerados tais aspectos, inúmeros fatores devem ser observados, quando se trata de adoção e guarda, com vistas ao melhor interesse da criança e do adolescente, p. ex.

o amor e os laços afetivos entre o titular da guarda e a criança; a habitualidade do titular da guarda de dar à criança amor e orientação; a habitualidade do titular da guarda de prover a criança com comida, abrigo, vestuário e assistência médica (os chamados alimentos necessários); qualquer padrão de vida estabelecido; a saúde do titular da guarda; o lar da criança, a escola, a comunidade e os laços religiosos; a preferência da criança, se ela tem idade suficiente para ter opinião. (PERES, 2006, p. 131)

Nesse norte, anota-se que em nenhum momento há expressa menção à sexualidade dos adotantes.

Citada autora explica que a sexualidade não restou discriminada no rol acima transcrito porquanto "não inibe o seu potencial de prover a criança com os recursos materiais e pessoais, incluindo-se aspectos de ordem emocional e moral" (PERES, 2006, p. 131), conforme preceitua a Constituição 
da República, quando traz todo o aparato conceitual do que entende pertinente a título de proteção do melhor interesse da criança, disposto no art. 227 e parágrafos.

Assim, verifica-se crescente o entendimento segundo qual os aplicadores do direito devem optar por soluções que efetivamente representem maiores benefícios para a criança e para o adolescentes, confrontando princípios constitucionais, de modo a aplicar com maior ênfase aquele que melhor se adeque ao caso concreto.

Explica-se. Convém, em observância aos princípios da dignidade da pessoa humana, da igualdade, da ampla proteção à família e no melhor interesse da criança e do adolescente, considerar-se a possibilidade de adoção a casais homoafetivos, utilizando-se de regra extensiva quanto ao reconhecimento de entidade familiar, a ver abrigos repletos de cidadãos impedidos de gozar de inúmeros direitos que a própria Constituição da República assegura.

De outro norte, vislumbra-se ser juridicamente possível de apreciação pedidos de adoção realizados por casais homoafetivos, na proporção em que buscam a ampliação de suas entidades familiares, que já se encontram devidamente estruturadas, com fundamento dos mesmos princípios acima lançados.

Dias (2001, p. 117) esclarece que a adoção por casais homoafetivos representa não apenas "solução menos gravosa para o menor, mas a melhor solução em muitos casos, principalmente em um país como o nosso, pois retira o menor da marginalidade, dando-lhe um lar cercado de afeto e atenção".

No mesmo sentido, enfatiza Peres (2006, p. 131-132) que a adoção por homossexuais, enquanto na compreensão de alguns não é vista como a situação ideal, menos ainda o é a permanência de crianças em instituições.

Por fim, cumpre anotar peculiar comentário da autora, por meio do qual expõe que os parâmetros norteadores de uma decisão estão estreitamente atrelados aos valores culturais da 
sociedade, o que, de modo sistemático, permite efetiva flexibilização, na medida em que o entendimento evolui conforme a própria sociedade. (PERES, 2006, p. 133)

Assim, somados todos os aspectos acima delineados, impõe-se reconhecer a existência de fundamento jurídico suficiente para a análise jurídica de pedidos pelo reconhecimento de direitos cujo mote ensejador são as relações homoafetivas, posto que alicerçados em preceitos constitucionalmente consagrados, aplicando-se meramente interpretação extensiva, com a finalidade maior de inclusão de cidadãos que permanecem à margem do ordenamento jurídico.

Nesse contexto, a principiologia constitucional analisada - dignidade da pessoa humana, direito à igualdade, direito à ampla proteção da família e efetivação da defesa do melhor interesse da criança -, é de suma importância para dar embasamento jurídico ao reconhecimento de direitos inerentes a todo e qualquer cidadão enquanto inserido em um núcleo familiar, independentemente de sua orientação sexual.

\section{ADOÇÃo}

A finalidade proposta para o derradeiro capítulo é abordar aspectos gerais do instituto da adoção, lançando breve relato evolutivo da normatização, considerando os pressupostos relacionados do direito processual civil, mormente no que se refere às condições da ação, para desenvolver a abordagem central do presente estudo, qual seja, a possibilidade jurídica de adoção por casais homoafetivos.

\subsection{Notas introdutórias}

Adoção é tida como uma situação de fato, na qual um determinado lar recebe um estranho, ou seja, alguém que não é parte integrante da família enquanto considerados os laços de sangue, na qualidade de filho. (HIRSCHFELD, 2005, p. 1) 
Pressupõe considerar uma relação triangular, envolvendo três personagens portanto, o pai, a mãe e a criança, e nesse contexto surgiu o instituto na antiguidade, reproduzido no paradigma "dar filhos, artificialmente, a quem a natureza os negou”. Reproduziu-se o entendimento de que são os filhos que garantem ao casal a construção de um projeto comum, consubstanciado no acesso à família. (LEITE, 2005, p. 108)

Hirschfeld (2005, p. 1) define que a adoção

constitui-se em um ato jurídico bilateral, solene e complexo, criando relações idênticas àquelas decorrentes da filiação legítima, dando ao filho adotivo o mesmo status do filho biológico. Pela vontade dos particulares, os laços de filiação e paternidade são estabelecidos entre as pessoas que não possuem esta relação naturalmente. Torna o adotando, por consequência, filho de quem não é seu pai, abrangendo todos os direitos e deveres que o ato gera, cujos efeitos decorrem de lei, e não das partes, que não podem alterá-los.

Essa noção de triangularização da adoção sempre com vistas ao melhor interesse da criança, tendo o direito brasileiro absorvido tal característica, materializada desde o Código Civil de 1916, passando pelo Estatuto da Criança e do Adolescente (ECA) e, igualmente, materializada no Código Civil de 2002. (LEITE, 2005, p. 111)

Portanto, atualmente infere-se que a adoção considerada instituição com características humanitárias, estabelecendo, por um lado, liame legal de paternidade e filiação civil, e por outro lado, pressupõe finalidade assistencial, com vistas a melhorar as condições morais, materiais e emocionais da criança ou adolescente a ser adotado. (HIRSCHFELD, 2005, p. 2)

No mesmo sentido, pondera Leite (2005, p. 113) que em que pese reconhecer o legislador o "caráter filantrópico e assistencial da adoção no ECA, o texto legal reafirma a necessidade da família (família substituta) na triangulação do instituto". 
Atualmente a novel Lei n. 12.010 trouxe importantes modificações para o instituto da adoção, cumprindo realçar alguns tópicos, porquanto estreitamente relacionados ao tema.

A nova lei, a partir do art. 20 trouxe inúmeras alterações no que tange a artigos específicos da Lei n. 8.069/1990, regulando o acolhimento de criança e do adolescente em programa familiar ou institucional, fixando prazos de reavaliação de sua situação, bem como prazos máximos de permanência (art. 1927). Regulamentou também os casos de adoção de crianças indígenas e as obrigatoriedades a serem observadas em tais casos, art. 28, \$ $6^{\mathrm{o} 28}$.

Correlacionado ao tema em destaque, portanto, o art. $42 \mathrm{da}$ nova Lei n. 12.010/2009 dispõe que "podem adotar os maiores de 18 (dezoito) anos, independentemente do estado civil”.

E no $\$ 2$ acrescentou que "para a adoção conjunta, é indispensável que os adotantes sejam casados civilmente ou mantenham união estável, comprovada a estabilidade da família”.

Nesse norte, infere-se que foi suprimida do texto legal as expressões "marido e mulher" como anteriormente estava expresso no art. 1.622 do Código Civil de 2002, ou seja, afir-

26 Lei n. 12.010, de 3 de agosto de 2009. Dispõe sobre adoção; altera as Leis n: 8.069, de 13 de julho de 1990 - Estatuto da Criança e do Adolescente, 8.560, de 29 de dezembro de 1992; revoga dispositivos da Lei $n^{\circ} 10.406$, de 10 de janeiro de 2002 - Código Civil, e da Consolidação das Leis do Trabalho - CLT, aprovada pelo Decreto-Lei $n^{\circ} 5.452$, de $1^{\circ}$ de maio de 1943; e dá outras providências.

27 "Art. 19. (...) $\S 1^{\circ}$ Toda criança ou adolescente que estiver inserido em programa de acolhimento familiar ou institucional terá sua situação reavaliada, no máximo, a cada 6 (seis) meses, devendo a autoridade judiciária competente, com base em relatório elaborado por equipe interprofissional ou multidisciplinar, decidir de forma fundamentada pela possibilidade de reintegração familiar ou colocação em família substituta, em quaisquer das modalidades previstas no art. 28 desta Lei. $\S 2^{\circ} \mathrm{A}$ permanência da criança e do adolescente em programa de acolhimento institucional não se prolongará por mais de 2 (dois) anos, salvo comprovada necessidade que atenda ao seu superior interesse, devidamente fundamentada pela autoridade judiciária. § $3^{\circ} \mathrm{A}$ manutenção ou reintegração de criança ou adolescente à sua família terá preferência em relação a qualquer outra providência, caso em que será esta incluída em programas de orientação e auxílio, nos termos do parágrafo único do art. 23, dos incisos I e IV do caput do art. 101 e dos incisos I a IV do caput do art. 129 desta Lei." (NR)

28 Art. $4^{\circ}$. Quando a lei for omissa, o juiz decidirá o caso de acordo com a analogia, os costumes e os princípios gerais de direito. (BRASIL, 2009) 
mava-se que "ninguém poderá ser adotado por duas pessoas, salvo se forem marido e mulher, ou se viverem em união estável".

Atualmente, a utilização da expressão adotantes deixou de restringir a possibilidade de adoção somente a marido e mulher ou mantenedores, nestas condições, de união estável, ou seja, utilizando expressão aberta (adotantes) deu a oportunidade aos aplicadores do direito de interpretação da lei de acordo com os anseios sociais, mormente aos casos de adoção por casais homoafetivos.

\subsection{Ação de Adoção}

Afirma Santos (2007, p. 154), de modo genérico, que a ação é um direito, sendo que a controvérsia principal que se estabelece diz respeito à natureza desse direito posto em litígio.

De modo semelhante, para Theodoro Júnior (2000, p. 43) a ação é o "direito subjetivo à tutela jurisdicional".

Atualmente, compreende Pereira (2008, p. 73) que "ação é o direito de provocar a tutela jurisdicional. É a resposta estatal à supressão da justiça de caráter privado”.

Nesse sentido, o conceito de ação - do direito processual civil - centraliza-se na idéia de indivíduos, seus bens, seus direitos, seus interesses, e o Estado na sua função jurisdicional. Gerado o conflito, vedada a autodefesa, tendo o Estado reservado para si a função jurisdicional, surge para o interessado o direito de fazer valer aquele direito, aquele interesse por via do próprio Estado, isto é, "o direito de de exigir-lhe a prestação jurisdicional, fazendo atuar a vontade da lei”. (SANTOS, 2007, p. 166)

Assim, tem-se que esse direito subjetivo, de caráter público, que tem por sujeito passivo o próprio Estado, é o direito de ação.

Essas definições são de aplicação subsidiária à ação de adoção, que a despeito de possuir características peculiares e exigir o preenchimento de requisitos específicos, não se distancia 
daquilo que o Código de Processo Civil disciplina, assim como do preenchimento dos pressupostos processuais e das condições da ação.

Guimarães (2003, p. 36) explica que a adoção de crianças e de adolescentes é "regida pela Lei n. 8.069, de 13 de julho de 1990, conforme disposto no art. 39 e, subsidiariamente, pelas regras contidas no novo Código Civil que não sejam com ela incompatíveis, sendo imprescindível o processo judicial".

O autor sustenta que o objetivo da ação de adoção é perfectibilizar no plano processual a atribuição de condição de filho ao adotado, com idênticos direitos e deveres, inclusive sucessórios, aos dos filhos biológicos, desligando-o de qualquer vínculo com os pais e parentes consanguíneos, salvo impedimentos de ordem matrimonial. (GUIMARÃES, 2003, p. 37)

Não obstante inúmeras críticas em relação ao ECA, é este estatuto que se aplica para os pedidos de adoção. Diante disso, Silva Júnior $(2008$, p. 96) traça os requisitos e as exigências indispensáveis, nominando-as de avanço normativo, afirmando que após a promulgação da Lei n. 8.6069/1990, o Estatuto da Criança e do Adolescente, na senda evolutiva deflagrada pela Carta Magna, encontrou na adoção o vínculo jurídico afetivo da filiação.

Segundo Silva Júnior (2008, p. 96) o ECA representou um avanço jurídico-normativo considerável, transcendendo preconceitos de qualquer natureza, assim como não se verificam na legislação infraconstitucional - que regem a matéria -, ou na legislação constitucional - que lhe dá suporte -, mas sim, emergem da hermenêutica literal ou vinculada a concepções jurídica já ultrapassadas.

No que tange a questões processuais, de acordo com o princípio geral de proteção integral adotado pelo Estatuto da Criança e do Adolescente, vê-se que os processos afetos à Justiça da Infância e da Juventude têm como característica a simplificação dos procedimento, admitindo certa informalidade a 
fim de garantir acesso rápido aos interessados e celeridade na solução da lide. (GUIMARÃES, 2003, p. 49)

Considerando tais aspectos infere-se que não há qualquer vedação de ordem legal que impeça a postulação por casal homoafetivo de adoção de criança ou adolescente, com fundamento no ECA e no princípio do melhor interesse da criança.

Nesse sentido, defende Silva Júnior (2008, p. 97) que para a viabilidade de constituição do vínculo adotivo de filiação entre um menor e um casal de pessoas do mesmo sexo mister que estejam preenchidas as exigências legais, com resultado de estudo psicossocial favorável e decisão judicial cuja fundamentação leve em conta a estabilidade da união homossexual, aplicando-se, portanto, analogicamente a legislação pertinente a união estável.

\subsection{Condições da Ação}

Assim como anteriormente afirmado, a ação é o direito subjetivo de pedir ao Estado a prestação da atividade jurisdicional num caso concreto, que se manifesta na pretensão formulada pelo autor para a qual pede a tutela jurisdicional ao Estado, que, ao final, profere decisão acolhendo-a ou rejeitandoa. (SANTOS, 2007, p. 175)

Pereira (2008, p. 81) explica que as condições da ação representam uma "relação de logicidade entre a versão do autor e o seu pedido, tendo em vista a viabilidade da provocação da jurisdição".

Isso porque, "embora abstrata, a ação não é genérica, de modo que, para obter a tutela jurídica, é indispensável que autor demonstre uma pretensão idônea a ser objeto da atividade jurisdicional do Estado”. (THEODORO JÚNIOR, 2000, p. 46)

Assim, para o regular exercício deste direito de ação, é necessário o preeenchimento de alguns requisitos, ou seja, o direito de ação subordina-se ao preenchimento a certas condições, sendo que na falta de qualquer uma delas, há carência 
de ação, restando o órgão jurisdicional dispensado de decidir o mérito da pretensão deduzida. (SANTOS, 2007, p. 176-177.

As duas primeiras condições da ação estão expressas, como se vê do art. 3o do Código de Processo Civil, quais sejam, interesse e legitimidade. A terceira condição da ação, nominada de "possibilidade jurídica do pedido", decorre de interpretação doutrinária oriunda do somatório daquelas expressamente previstas do art. $3^{\circ}$ - interesse e legitimidade.

Tais regras, por conseguinte, dentre outras tidas por específicas, aplicam-se subsidiariamente à ação de adoção, na medida em que sem o seu preenchimento a pretensão de adoção não terá guarida. As condições da estão dispostas no Código de Processo Civil e são (i) interesse de agir e (ii) qualidade para agir - legitimidade, e, por fim, (iii) a possibilidade jurídica do pedido. (SANTOS, 2007, p. 177)

Interesse de agir (i), segundo Santos (2007, p. 178) é o direito de agir, é o direito de ação, distinto, porém, do direito material a que se visa tutelar. Há portanto, um interesse primário consubstanciado no direito substancial, ou seja, no bem jurídico, material ou incorpóreo, pretendido pelo autor.

E há, ainda, outro interesse, aquele que move a ação. É o interesse pela obtenção de uma providência jurisdicional quanto àquele interesse primário, logo, há interesse de agir, de reclamar a tutela jurisdicional do Estado quando há um interesse primário a se tutelado pelo Estado. (SANTOS, 2007, p. 178)

No caso, o interesse de agir traduz-se na necessidade que o adotante tem de provocar o Estado a fim de que seja tutelado o seu interesse pela adoção de outrem. A utilidade refere-se à vantagem perseguida pelos interessados com a procedência do provimento jurisdicional e a adequação, por fim, diz respeito à existência de coerência entre o pedido de adoção realizado e o mecanismo processual escolhido pelo autor. 
A legitimidade para agir (ii), conforme já registrado, é a qualidade para agir, ou seja, o autor deve ter título em relação ao interesse que pretende seja tutelado. (SANTOS, 2007, p. 179)

Para Pereira (2008, p. 81) a legitimidade de agir corresponde à "pertinência entre a descrição processual e a definição das correspondentes relações jurídicas, no plano do direito material”.

Assim, certo que tem legitimidade para agir na ação de adoção aquele que demonstre a pertinência subjetiva da ação, ou seja, a descrição processual deve, obrigatoriamente, corresponder à relação jurídica, no plano de direito material.

Finalmente, a condição da ação chamada possibilidade jurídica (iii), segundo SANTOS (2007, p. 178) pressupõe que o direito de ação imponha que o seu exercício vise à obtenção de uma providência jurisdicional sobre uma pretensão tutelada pelo direito objetivo.

Para o exercício do direito de ação a pretensão formulada pelo autor deverá ser de natureza a poder ser reconhecida em juízo, ou seja, o pedido deverá consistir numa pretensão que, em abstrato, seja tutelada pelo direito objetivo. (SANTOS, 2007, p. 178)

A respeito da possibilidade jurídica de adoção de crianças e adolescentes, conforme exaustivamente abordado, cediço que existe expressa previsão legal, cujo objetivo maior é o melhor interesse do adotando [criança e adolescentes], assim como expõe o ECA e o Código Civil, com as alterações introduzias pela Lei n. 12.1010/2009.

Por outro lado, acerca da temática em estudo, em que pese inexistir no ordenamento jurídico autorização expressa, não há, de modo semelhante, vedação, na medida em que, com fundamento nos princípios constitucionais anteriormente esboçados, é possível estabelecer interpretação extensiva a respeito do art. 226, § 3o da Carta Magna, a fim de incluir em sua abrangência a adoção por casais homoafetivos. 


\subsection{Possibilidade Jurídica de Adoção por Casais Homoafetivos}

Silva Júnior (2007, p. 134) diz que "não emprestando juridicidade às uniões homossexuais, o legislador contribui para a marginalização dos que se atraem pelo mesmo sexo biológico".

Dias (2009b) defende que além de retrógrada, a negativa de reconhecimento é inconstitucional, pois é expressa a proibição de quaisquer designações discriminatórias relativas à filiação, ou seja, "rejeitar a homoparentalidade afronta um leque de princípios, direitos e garantias fundamentais, posto que crianças e adolescentes têm, com absoluta prioridade, direito à vida, à saúde, à alimentação, à convivência familiar, e negar o vínculo de filiação é vetar o direito à família (...)".

Para Peres (2006, p. 89-91) na ausência de lei específica o juiz deve julgar utilizando-se da analogia, dos costumes e dos princípios gerais de direito, conforme se depreende do art. $4^{\circ}$ da Lei de Introdução ao Código Civil brasileiro. Nesse sentido, contemporaneamente, passa a surgir a interpretação segundo a qual não mais se concebe os princípios como fonte subsidiária de terceiro grau, cuja função restringe-se a colmatar lacunas.

É urgente que se decida com vistas a conformar o ordenamento legal aos anseios sociais, harmonizando a legislação infraconstitucional à Lei Maior, não só no que pertine a considerar a união homoafetiva como família, mas a viabilidade de deferimento de pedido de adoção a casal homossexual, cuja união estável seja sólida, estável e desde que preenchidos os requisitos específicos da ação de adoção. (SILVA JÚNIOR, 2007, p. 134-135)

Assim, os princípios gerais de direito, surgem para além da função meramente integradora, e passam a desempenhar função interpretativa, acreditando-se, nesse sentido, exatamente para a qual foram concebidos. (PERES, 2006, p. 92-93)

Portanto, é perfeitamente aplicável, por analogia, enquanto inexistir norma específica que regulamente os efeitos de uniões homoafetivas, a legislação pertinente aos vínculos familiares 
com base na união estável, abrindo-se, por conseguinte, a possibilidade de reconhecimento da convivência afetiva homossexual como união estável digna de reconhecimento familiar, e, por consequência, dos efeitos gerados a partir disso. (SILVA JÚNIOR, 2007, p. 136)

A par disso, no que respeita à adoção, a aplicação dos princípios da dignidade da pessoa humana, da igualdade, da proteção à família e, mormente, o da proteção à criança e ao adolescente, considerando-se a defesa do seu melhor interesse são o fundamento do reconhecimento da possibilidade jurídica de adoção por casais homoafetivos.

Sustenta Silva Júnior (2007, p. 137) que "não existe argumento jurídico-científico plausível, nem óbice legal, no ordenamento brasileiro, para fundamentar a negativa dessa possibilidade” jurídica de adoção por casais homossexuais.

Atualmente, inúmeras modificações ampliaram a estrutura familiar, deslocando-se o centro de tutela constitucional do casamento para as relações familiares daí decorrentes e para aquelas outras formadas independentemente de sua ocorrência, tutelando-se, portanto, a dignidade de todos os membros inseridos na família, assegurando com maior rigor o respeito ao desenvolvimento da personalidade dos filhos. (PERES, 2006, p. 106)

Nesse contexto, deve ser inserida a família homoafetiva.

Primeiramente, porque com o reconhecimento jurídico a respeito de sua existência como família e com fundamento no direito fundamental da dignidade da pessoa, humana no que respeita aos seus membros, possa-se, paulatinamente, reconhecer direitos, mormente a hipótese aqui defendida, da possibilidade jurídica de adoção por seus pares.

De outro lado, com fundamento no princípio da igualdade, não se pode mais conceber a exclusão da família homoafetiva e da possibilidade de adoção por casais homoafetivos do ordenamento jurídico, sob pena de grave lesão ao dispositivo constitucional.

Num terceiro momento, no que tange ao princípio da ampla proteção à família, afirma Peres (2006, p. 110) que os 
indivíduos tem constitucionalmente assegurado o direito de formar uma família, somado-se a isso o fato de que a própria Constituição da República assegura o direito à igualdade conforme acima sustentado -, constituindo-se, pois, num dos seus objetivos fundamentais

Nesse sentido, considerando-se, tão-somente, tal direito fundamental [dignidade da pessoa humana], somado aos princípios constitucionais [igualdade e ampla proteção à família], é certo que em caso de vedação do direito de adoção a casal homossexual, meramente em razão de sua opção sexual, estar-se-ia ferindo o que a Constituição da República assegura. (PERES, 2006, p. 111)

Por fim, o derradeiro fundamento à garantia da possibilidade jurídica de adoção por casais homoafetivos repousa, em nosso ordenamento no art. $5^{\circ}, \S 2^{\circ}$ da $\mathrm{CRFB}^{29}$, norma cogente, de observação obrigatória, em especial pelas autoridades públicas, o que implica aferição da situação de fato da criança ou do adolescente a ser adotado, considerando aspectos relacionados à exclusão proporcionada pela manutenção em abrigos, nos quais há evidente ausência dos direitos subjetivos.

A possibilidade jurídica de adoção por casais homoafetivos vem ao encontro dessa omissão estatal e no efetivo resguardo do melhor interesse da crianças e adolescentes, principalmente daqueles que se encontram abrigados, privados de uma melhoria em sua condição de vida em relação à situação anterior, de segurança, de proteção, de cuidados, educação, afeição, integração em família com a qual se desenvolvam laços afetivos.

Enfim, diante de todo o contexto, procura-se dar atenção especial às condições de desenvolvimento da personalidade das crianças e adolescentes, assim como as reais vantagens de ordem moral e material, sendo aquelas priorizadas em relação a essas, encontrando na adoção por casais homoafetivos, que mantenham união duradoura e sólida, a efetividade de todos esses direitos tão amplamente garantidos se considerada a teorização

$29 \S 2^{\circ}$ - Os direitos e garantias expressos nesta Constituição não excluem outros decorrentes do regime e dos princípios por ela adotados, ou dos tratados internacionais em que a República Federativa do Brasil seja parte. (BRASIL, 2009) 
constitucional e infraconstitucional, porém, corriqueiramente negados, em face da ausência de oportunidade.

A manutenção de crianças e adolescentes em abrigos ao argumento de que a adoção por casais homoafetivos não encontra previsão legal lesiona o sistema jurídico constitucional e infraconstitucional como um todo, na medida em que fere frontalmente direitos e princípios consagrados, quer seja no que tange aos homossexuais que não tem seus direitos efetivamente assegurados, quer seja em relação à manutenção de crianças e adolescentes aptos à adoção privados de inserção em uma família.

Dias (2009a) acrescenta que "a dificuldade em deferir adoções exclusivamente pela orientação sexual ou identidade de gênero acaba impedindo que expressivo número de crianças sejam subtraídas da marginalidade”. Salienta a autora que é "imperioso arrostar nossa realidade social, com um enorme contingente de menores abandonados ou em situação irregular, quando poderiam ter uma vida cercada de carinho e atenção”.

Nesse sentido, torna-se inaceitável manter-se a exclusão de crianças e adolescentes causada primeiramente pelo abandono de seus entes familiares biológicos, e, num segundo momento, pelo próprio Estado.

O deferimento de pedido de adoção "não pode estar condicionado à preferência sexual ou à realidade familiar do adotante, sob pena de infringir-se o mais sagrado cânone do respeito à dignidade humana, que se sintetiza no princípio da igualdade e na vedação de tratamento discriminatório de qualquer ordem”. (DIAS, 2009a)

Diante do contexto, Andrade (2005, p. 120) arremata que diante da lacuna existente, lança-se mão de interpretação dos princípios constitucionais e concluí-se que as relações homoafetivas e as consequências delas geradas estão protegidas pela Carta Magna. Logo, ao interpretar o princípio da dignidade da pessoa humana, fundamento da República Federativa do Brasil e do Estado Democrático de Direito, vê-se que o Estado e todos os demais cidadãos são obrigados a reconhecer e respeitar, sem 
discriminações de qualquer ordem e independentemente de orientação sexual, qualquer tipo de relação.

Assim, na ausência de regulamentação legal, o choque entre direitos e princípios é evidente, sendo necessário, na aplicação ao caso concreto, aferir-se o de maior grandeza, a fim de garantir a efetivação da mais ampla gama de benefícios aqueles que se encontram privados do reconhecimento jurídico de sua situação como família afetivamente constituída, por mera ausência de expressão legal.

\section{CONCLUSÃo}

Objetivou-se contribuir para a compreensão dos conflitos relacionados à homoafetividade, contextualizada na sociedade contemporânea, mormente defendendo a possibilidade jurídica de adoção por casais homossexuais a partir de uma análise principiológica constitucional.

Diante da problemática proposta o assunto foi dividido em três grandes ramos do direito, em relação ao Direito Civil, por meio do qual traçaram-se os parâmetros do direito de família, estabelecendo-se conceituação e critérios de reconhecimento do instituto, bem como no que tange à adoção, sua estrutura legal e evolução legislativa até a atualidade; com o Direito Constitucional, na medida em que nele repousam as garantias primordiais da ordem jurídica e do cidadão, cujo fundamento são a República Federativa do Brasil e o Estado Democrático de Direito; e, por fim, procurou-se no Direito Processual Civil o regramento específico acerca do direito de ação e seus pressupostos.

Nesse contexto, é fundamental que se estabeleça discussão constante sobre temas que envolvem o reconhecimento de direitos e garantias a cidadãos, posto que a marginalização gerada em face da inexistência de previsão legal sobre direitos e deveres de considerável parcela da população é inconcebível pós Constituição Federal/1988, pois nesta repousam expressamente o reconhecimento de direitos fundamentais e de princípios norteadores da vida em sociedade. 
O reconhecimento das uniões homoafetivas públicas e duradouras como família é urgente, porquanto a partir deste momento poderão ser reconhecidos inúmeros outros direitos e também deveres que surgem destes relacionamentos. A possibilidade jurídica de adoção por casais homoafetivos, surge, nesse contexto, naturalmente, como solução que possui duas facetas bem delineadas, a primeira relativa a possibilidade de se dar filhos a esses casais e a segunda, calcada na garantia de dar um lar às crianças e aos adolescente que não o tem.

O estudo procurou fundamento da Constituição da República para traçar os parâmetros processuais que visem a procedência de ação de adoção pleiteada por casal homoafetivo, sendo certo que não o esgotou. Portanto, verifica-se que diante dos direitos fundamentais inseridos no texto constitucional, assim como dos princípios norteadores da Carta Constitucional, há possibilidade jurídica de adoção por casais cujo vínculo familiar duradouro, público e notório, repousa na afetividade.

Convém, por fim, registrar que a presente abordagem não tem a pretensão de ser definitiva, mas, tão-somente, flexível, cuja abertura da temática possa dar continuidade ao estudo e à discussão, instigando-se a percepção de questões postas na sociedade contemporânea, para as quais o direito não pode mais negar-se o reconhecimento.

Abstract: This article presents the legal possibility of adoption by homosexual couples on the basis of constitutional principles of human dignity, equality, ample protection of the family and full protection of children and adolescents in order to defend the best interest and ensure the recognition of rights.

The article defines family based on affection and seeks to establish guarantees for the legal possibility of adoption by same-sex couples, by interpretation of the constitutional principles. Therefore, the subject of this study appears in the absence of legal regulation and the obvious conflict between principles, requiring to assess which is the greater magnitude, in 
order to ensure the realization of the widest range of rights, especially those who are outside the planning legal, since the mere absence of legal expression can no longer be accepted as a impediment to the recognition of fact situations which generates important consequences in the legal field.

Keywords: Family. Constitutional principles. Action conditions. Legal possibility request.

\section{REFERÊNCIAS}

AZEVEDO, Álvaro Villaça. União homoafetiva. Revista Jurídica Consulex, Brasília, Ano VIII, n. 181, p.42-44, 31 jul. 2004. Mensal.

BONAVIDES, Paulo. Curso de Direito Constitucional. 23 ed. São Paulo: Malheiros, 2008.

BRASIL. Constituição (1988). Constituição da República Federativa do Brasil. 42. ed. São Paulo: Saraiva, 2009.

. Decreto-Lei n. 4.657, de 4 de setembro de 1942. Lei de Introdução ao Código Civil brasileiro. Disponível em: http://www.planalto.gov.br/ ccivil 03/Decreto-Lei/Del4657.htm. Acesso em 8/12/2009.

. Lei n. 3.071, de 1o de janeiro de 1916. Código Civil. Revogada pela Lei n. 10.406, de 10 de janeiro de 2002. Disponível em: http://www. planalto.gov.br/ccivil 03/LEIS/L3071.htm. Acesso em 16/8/2009.

Lei n. 5.869, de 11 de janeiro de 1973. Institui o Código de processo Civil. Disponível em: http://www.planalto.gov.br/ccivil 03/ LEIS/L5869.htm. Acesso em 6/12/2009.

. Lei n. 8.069, de 13 de julho de 1990. Dispõe sobre o Estatuto da Criança e do Adolescente e dá outras providências. Disponível em: http:// www.planalto.gov.br/ccivil 03/Leis/L8069.htm. Acesso em 2/12/2009.

. Lei n. 8.971, de 29 de dezembro de 1994. Regula o direito dos companheiros a alimentos e à sucessão. Disponível em: http://www.planalto. gov.br/ccivil 03/Leis/L8971.htm. Acesso em 30/8/2009.

. Lei n. 9.278, de 10 de maio de 1996. Regula o §3º do art. 226 da Constituição Federal. Disponível em: http://www.planalto.gov.br/ccivil 03/ Leis/L9278.htm. Acesso em 30/8/2009. 
. Lei n. 10.406, de 10 de janeiro de 2002. Institui o Código Civil. Disponível em: http://www.planalto.gov.br/ccivil 03/LEIS/2002/L10406. htm. Acesso em 16/8/2009.

Lei n. 12.1010, de 3 de agosto de 2009. Dispõe sobre adoção; altera as Leis $\mathrm{n}$ OS 8.069 , de 13 de julho de 1990 - Estatuto da Criança e do Adolescente, 8.560, de 29 de dezembro de 1992; revoga dispositivos da Lei $\mathrm{n}-10.406$, de 10 de janeiro de 2002 - Código Civil, e da Consolidação das Leis do Trabalho - CLT, aprovada pelo Decreto-Lei n⿳⿵人一 5.452, de 1 O de maio de 1943; e dá outras providências. Disponível em http://www.planalto.gov.br/ccivil 03/ Ato2007. 2010/2009/Lei/L12010.htm\#art8. Acesso em 2/12/2009.

ANDRADE, Diogo de Calasans Melo. Adoção por Casais Homossexuais: adoção entre pessoas do mesmo sexo e os princípios constitucionais. Revista Brasileira de Direito de Família, Porto Alegre, v. 30, n. , p.99-123, jun. 2005.

CANOTILHO, J.J. Gomes. Direito Constitucional e Teoria da Constituição. 7. ed. Coimbra: Almedina, 2003.

CAVALCANTI, Ana Elizabeth Lapa Wanderley. Casamento e União Estável: requisitos e efeitos pessoais. São Paulo: Manole, 2004.

COELHO, Fábio Ulhoa. Curso de Direito Civil. São Paulo: Saraiva, 2006. 5 v.

DIAS, Maria Berenice. A União Homossexual e a Constituição Federal, in Revista Brasileira de Direito de Família.

DIAS, Maria Berenice. Adoção Homoafetiva. Disponível em: http://www. mariaberenicedias.com.br/site/content.phpcont $\mathrm{id}=479 \&$ isPopUp=true. Acesso em: 9/12/2009.

DIAS, Maria Berenice. Filiação Homoafetiva. Disponível em: http://www. mariaberenicedias.com.br/site/content.php?cont id=387\& isPopUp=true. Acesso em: 9/12/2009.

DIAS, Maria Berenice. União Homossexual: o preconceito \& a justiça. Porto Alegre: Livraria do Advogado, 2001.

DINIZ, Maria Helana. Curso de Direito Civil Brasileiro: Direito de Família. 24. ed. reformulada. São Paulo: Saraiva, 2009. 5 v.

ENGELS, Friedrich. A Origem da Família, da Propriedade e do Estado: trabalho relacionado com as investigações de L. H. Morgan. 12. ed. Rio de Janeiro: Bertrand Brasil S.A., 1991.

FERREIRA, Aurélio Buarque de Holanda. Miniaurélio: o dicionário da língua portuguesa. 7. ed. Curitiba: Positivo, 2008. 
FUGIE, Érika Harumi. A União Homossexual e a Constituição Federal: inconstitucionalidade do artigo 226, § $3^{\circ}$, da Constituição Federal. Revista Brasileira de Direito de Família, São Paulo, v. 813, n. 15, p.131-150, out., nov., dez. 2002.

GUIMARÃES, Giovane Serra Azul. Adoção, Tutela e Guarda - Conforme o Estatuto da Criança e do Adolescente e o Novo Código Civil. 2. ed. rev. atual. e ampl. São Paulo: Juarez de Oliveira, 2003.

HIRSCHFELD, Adriana Kruchin; LEITE, Eduardo de Oliveira (Org.).

Grandes temas da atualidade $\llbracket$ Adoção: aspectos jurídicos e metajurídicos. Rio de Janeiro: Forense, 2005.

LAKATOS, Eva Maria et MARCONI, Marina de Andrade. Metodologia Científica. 2. ed. São Paulo: Atlas, 1991.

LEITE, Eduardo de Oliveira (Org.). Grandes temas da atualidade $\llbracket$ Adoção: aspectos jurídicos e metajurídicos. Rio de Janeiro: Forense, 2005.

MATOS, Ana Carla Harmatiuk. União entre pessoas do mesmo sexo: aspectos jurídicos e sociais. Belo Horizonte: Del Rey, 2004.

MACEDO, Emilisa Curi de; LEITE, Eduardo de Oliveira (Org.). Grandes temas da atualidade $\square$ Adoção: aspectos jurídicos e metajurídicos. Rio de Janeiro: Forense, 2005.

MONTEIRO, Washington de Barros. Curso de Direito Civil: direito de família. 37. ed. São Paulo: Saraiva, 2004. 2 v.

MORAES, Alexandre de. Direito Constitucional. 18. ed. São Paulo: Atlas, 2005.

MORAES, Maria Celina Bodin de. Danos à Pessoa Humana: uma leitura civilconstitucional dos danos morais. Rio de Janeiro: Renovar, 2003.

NAHAS, Luciana Faísca. União Homossexual: Proteção Constitucional. Curitiba: Juruá, 2008.

NERY JUNIOR, Nelson; NERY, Rosa Maria de Andrade. Código Civil Comentado. 6. ed. São Paulo: Revista dos Tribunais, 2008.

PASOLD, Cesar Luiz. Prática da Pesquisa Jurídica. 4. ed. Florianópolis: OAB/ SC Editora, 2000.

PEREIRA, Caio Mário da Silva. Instituições de Direito Civil: direito de família. 14. ed. Rio de Janeiro: Forense, 2004. 5 v. 
PEREIRA, Hélio do Valle. Manual de Direito Processual Civil: Roteiros de aula - Processo de Conhecimento. 2. ed. Florianópolis: Conceito Editorial, 2008.

PERES, Ana Paula Ariston Barion. A Adoção por Homossexuais: fronteiras da família da pós-modernidade. Rio de Janeiro: Renovar, 2006.

PINTO, Antonio Luiz de Toledo; WINDT, Márcia Cristina Vaz dos Santos; CÉSPEDES, Livia (Colab.) Código Civil e Constituição Federal. 60. ed. São Paulo: Saraiva, 2009.

RIOS, Roger Raupp. Orientação sexual e combate à discriminação: direito à igualdade ou direito à diferença? Distribuição ou reconhecimento? Universalismo ou particularismo? In: SHÄFER, Jairo (Org.). Temas polêmicos do constitucionalismo contemporâneo. Florianópolis: Conceito Editorial, 2007.

RODRIGUES, Silvio. Direito Civil: direito de família. 28. ed. São Paulo: Saraiva, 2004. $6 \mathrm{v}$.

SANTOS, Boaventura de Sousa. Para uma revolução democrática da justiça. 2. ed. São Paulo: Cortez, 2008.

SANTOS, Moacyr Amaral. Primeiras linhas de direito processual civil. 25. ed. São Paulo: Saraiva, 2007. 1 v.

SILVA, José Afonso da. Curso de Direito Constitucional Positivo. 32. ed. São Paulo: Malheiros, 2008.

SILVA JÚNIOR, Enézio de Deus. A possibilidade jurídica de adoção por casais homossexuais. 3. ed. Curitiba: Juruá, 2007.

TAVARES, André Ramos. Curso de Direito Constitucional. 3. ed. São Paulo: Saraiva, 2006.

THEODORO JúNIOR, Humberto. Curso de Direito Processual Civil. 31. ed. Rio de Janeiro: Forense, 2000. $1 \mathrm{v}$.

VENOSA, Sílvio de Salvo. Direito Civil: direito de Família. 8. ed. São Paulo: Atlas, 2008. 6 v.

WELTER, Belmiro Pedro. Família homoafetiva: Limites Constitucionais. Revista Brasileira de Direito de Família e Sucessões, Belo Horizonte, v. 2, fev./mar. 2008, p.69-86, 01 fev. Bimestral. 